ANNA GIBEK ${ }^{1}$

\title{
Wino weselne w Kanie Galilejskiej i jego symboliczne znaczenie (] 2, 1-11)
}

Ślub i wesele to wyjątkowe chwile w życiu ludzkim, które programują następującą po nich wspólną, wieloletnią codzienność. Ta ważna uroczystość przebiega w atmosferze radości, wyrażonej również przez goszczący na stołach alkohol. Podobnie było w czasach i krajach biblijnych. Zarówno uroczystościom weselnym, jak i codzienności towarzyszyło wino - napój sporządzany z owoców winorośli, dla których klimat krajów Bliskiego Wschodu jest wyjątkowo przychylny.

Święty Jan Ewangelista opisał wesele, na którym wino odgrywa dość znaczącą rolę. Nakreślając tło uroczystości zaślubin w czasach biblijnych, znaczenie i symbolikę wina w Piśmie Świętym, warto pochylić się nad wymową wina w opisanych godach w Kanie. Ponieważ ewangelie są dziełem chrystocentrycznym, należałoby również zastanowić się: jakiego Jezusa przedstawia opisane wydarzenie? Odpowiedzi na powyższe pytania spróbuje dać to opracowanie.

1 Mgr lic. Anna Gibek - doktorantka teologii biblijnej, pedagog. Autorka monografii i kilkunastu artykułów naukowych. Przedmiot badawczy: małżeństwo i rodzina w Biblii, Ewangelie synoptyczne. 


\section{Zaślubiny w Kanie Galilejskiej}

Na uroczystości weselnej opisanej w Ewangelii św. Jana gościli Jezus z uczniami i Maryja. Zaślubiny miały miejsce w Kanie Galilejskiej. Obecnie rozważa się dwie lokalizacje tego wydarzenia: według badaczy jest to albo Chirbet Qana, miejsce zlokalizowane $9 \mathrm{~km}$ od Seforis i 14 od Nazaretu ${ }^{2}$, albo odwiedzane przez pielgrzymów Kefar Kanna, leżące $3 \mathrm{~km}$ od Seforis ${ }^{3}$.

Zawarcie małżeństwa było dla Żydów jednym z najważniejszych momentów w życiu. Dojrzałość płciową młodzież Bliskiego Wschodu uzyskiwała już w wieku 10-12 lat, jednak za czas odpowiedni do małżeństwa uważano odpowiednio 12-13 lat dla kobiet i 18-20 dla mężczyzn. Z inicjatywą wspólnej przyszłości wychodził ojciec pana młodego lub sam zainteresowany ${ }^{4}$, dziewczyna musiała cierpliwie czekać na przyszłego małżonka. Chcąc poślubić kobietę, należało jej ojcu wpłacić mohar wynoszący około 30-50 sykli srebra ${ }^{5}$. W ten sposób zawierana była umowa małżeńska, która w praktyce oznaczała zaręczyny dziewczyny.

Okres narzeczeństwa trwał rok, ale dla wdów mógł być skrócony do miesiąca. Ojciec dziewczyny uposażał córkę, a zdobyty w ten sposób majątek pozostawał jej własnością na wypadek wdowieństwa lub oddalenia. Również przyszły małżonek wręczał wybrance mattan, do którego nigdy nie traciła praw.

2 Więcej na temat Chirbet Qany por. http://www.biblewalks.com/Sites/khirbetcana. html (20.04.2015).

3 Por. M. Rosik, Ziemia Stowa. Biblijny przewodnik po Ziemi Świętej. Izrael-JordaniaSynaj, Wrocław 2013, s. 212.

4 M. Rosik podaje, że w przypadku, gdy ojciec nie mógł aranżować małżeństwa syna, czyniła to matka. Por. M. Rosik, Judaizm u poczq̨tków ery chrześcijaństwa, Wrocław 2003, s. 168.

5 Wysokość opłaty była uzależniona od sytuacji ekonomicznej rodzin przyszłych małżonków. 
Po okresie narzeczeństwa następowało uroczyste wprowadzenie narzeczonej do domu męża, połączone z tygodniowym, bardzo hucznym weselem ${ }^{6}$. Pan młody, namaszczony olejkiem i wonnościami, przystrojony przez matkę $\mathrm{w}$ wieniec, $\mathrm{w}$ białej szacie, $\mathrm{w}$ wigilię uroczystości wychodził naprzeciw wybrance w asyście przyjaciół i muzyków. Z domu panny młodej druhny wyprowadzały wybrankę, również wyjątkowo przystrojoną i najprawdopodobniej zasłoniętą welonem $^{7}$. Do tych radosnych pochodów po drodze przyłączali się inni, rozświetlając wieczorną ciemność pochodniami i lampionami. Tak docierano do domu weselnego i rozpoczynała się uroczystość czas radości, żartów, jedzenia, picia, śpiewów i tańców.

W pierwszy wieczór małżonek wypowiadał formułę małżeńską: „Ja [...] będę dla ciebie mężem. Ty [...] będziesz dla mnie żoną ${ }^{8}$. Na znak objęcia żony w posiadanie pan młody mógł narzucić wybrance skraj swojej szaty. Biorąc kobietę za żonę, podejmował się troski o nią i jej ochrony. Następnie wszyscy goście błogosławili młodej parze. Po uroczystym posiłku żona zasiadała pod baldachimem (chuppa) i odbierała prezenty. Wieczorem orszak weselny odprowadzał nowożeńców do specjalnie przygotowanej komnaty, gdzie dopełniano małżeństwa. Wesele, zabawa i radość trwały przez kilka następnych dni9.

Analizując biblijny temat zaślubin i wesela, warto zwrócić uwagę na symboliczne starotestamentowe znaczenie godów małżeńskich.

6 Wesele trwało tydzień w przypadku dziewicy, ślub wdowy świętowano dwa albo trzy dni.

7 Inną wersję tradycji podaje C. J. Wenham, twierdząc, że pan młody z orszakiem dochodził do domu oblubienicy, pozdrawiał rodzinę, przekazywał dary, a następnie wypijał kilka pucharów i procesja wyruszała do domu pana młodego. Por. G. J. Wenham, Zaślubiny, [w:] Słownik wiedzy biblijnej, red. B. M. Metzger, M. D. Coogan, tłum. A. Karpowicz i in., Warszawa 2004, s. 815.

8 Cyt. za: S. Szymik, Małżeństwo i rodzina w Biblii, [w:] Życie społeczne w Biblii, red. G. Witaszek, Lublin 1998, s. 211.

9 Por. F. Rienecker, G. Maier, Leksykon biblijny, red. nauk. wyd. pol. W. Chrostowski, tłum. D. Irmińska, uzup. J. Kruczyńska, Warszawa 2001, s. 467-469. 
Trwały związek pomiędzy mężczyzną a kobietą obrazował przymierze między Bogiem a narodem wybranym. Prorok Ozeasz, zapowiadając odnowienie przymierza, opisywał je jako uroczystość ślubną z wszystkimi przymiotami małżeństwa:

I stanie się w owym dniu - wyrocznia Pana - że nazwie Mnie: „mój Mąż”. [...] Poślubię cię sobie na wieki, poślubię cię sobie w sprawiedliwości i prawie, w dobroci i miłosierdziu. Poślubię cię sobie w wierności i poznasz $\mathrm{Pana}^{10}$. ( $\left.\mathrm{Oz} 2,18 ; 21-22\right)$

Również na przykładzie relacji małżeńskiej Deutero-Izajasz obrazuje stosunek Boga do Izraela:

Ponieważ twoim mężem jest twój Stwórca, który ma na imię Pan Zastępów. Twoim odkupicielem jest Święty Izraela, który nazywany jest Bogiem całej ziemi. Pan cię wezwał jak kobietę opuszczoną i przygnębioną, bo czy można porzucić żonę poślubioną w młodości? - mówi twój Bóg. (Iz 54, 5-6)

\section{Wino}

Porównanie miłości i więzi małżeńskiej do relacji Bóg - człowiek wskazuje na wyjątkowość związku kobiety i mężczyzny. W tym szczególnym dniu zawierania małżeństwa wszystkim obecnym towarzyszyło wino - napój radości.

Pozyskiwane z owoców winorośli, było mocno wpisane w codzienność czasów biblijnych. Do jego produkcji używano wykutych w skale kadzi wypełnionych winogronami, które wyciskano stopami; pozyskany sok z cząstkami miąższu spływał do niżej położonej

10 Cytaty z Biblii za: Pismo Święte Starego i Nowego Testamentu, oprac. zespół biblistów polskich z inicjatywy Towarzystwa św. Pawła, Częstochowa 2011. 
kadzi, gdzie był dalej wyciskany przy użyciu kamienia. Czysty sok przelewano do bukłaków i dzbanów, w których pozostawał przez cały okres fermentacji. $Z$ czasem popularne stało się wyciskanie winogron również prasą belkową, tak jak oliwek. Pito nie tylko wino, ale także świeżo wyciśnięty sok i taki też składano w ofierze pierwocin.

Chleb, wino i oliwa to trzy podstawowe artykuły żywnościowe Izraelitów; traktowane jako dar Boga (Ps 104, 14-15), były pokarmem i napojem, którego nie mogło zabraknąć przy radosnym świętowaniu i przy wspólnych posiłkach. Zarówno wina, jak i oliwy używano również jako środków leczniczych. Miłosierny Samarytanin, chcąc opatrzyć rany pobitego, zalał je winem i oliwą $(Ł k \text { 10, 34) })^{11}$.

Rozweselające serce wino było niejednokrotnie nadużywane (Am 6, 6), jednak taką postawę zawsze ganiono. Pijaństwo postrzegano negatywnie - upojenie się alkoholem to dowód głupoty ( $\operatorname{Prz} 20,1)$, skutki takiego stanu są kompromitujące i jego konsekwencje nieraz trwają przez całe życie. Najlepiej obrazują to historie Noego $(\mathrm{Rdz}$ 9, 20-27) i Lota (Rdz 19, 30-38). Nowy Testament zachęca, by oczekując przyjścia Pana, być trzeźwym, nie upijać się (Łk 12, 45). Święty Paweł szczególnie krytykuje pijaństwo podczas zebrań liturgicznych $\left(1\right.$ Kor 11, 20) ${ }^{12}$.

W starożytnym Izraelu były też grupy społeczne zachowujące abstynencję. Nie pili alkoholu kapłani w okresie sprawowania służby (Kpł 10, 8-11), nazirejczycy nie spożywali winogron w żadnej postaci (Lb 6, 3-4), a rekabici nie pili wina (Jr 35, 6). Autorzy biblijni mają pozytywny stosunek do wina, jeżeli nie jest ono nadużywane. Również Jezus i Jego uczniowie w życiu codziennym używali tego napoju.

Wino symbolizowało wszystko to, co przyjemne: dobrobyt (Prz 3, 10), przyjaźn (Syr 9, 10) miłość (Pnp 1, 4) i wszelaką radość (Koh 10, 19). Dlatego też czasy eschatologiczne charakteryzuje obfitość wina (Am 9, 14), blijny, dz. cyt., s. 855-857. 
a skutkiem niewierności i jednym ze sposobów karania jest pozbawienie jednostki tego napoju (Mi 6, 15).

Nowy Testament wprowadza nowe wino jako symbol czasów mesjańskich. Oto era starego wina się skończyła, przyjście Jezusa i ustanowienie Nowego Przymierza to czas nowego wina, które rozsadza stare bukłaki (Mk 2, 22). To czas nowej, prawdziwej i pełnej radości, miłości i dobroci ${ }^{13}$.

\section{Znaczenie wina na galilejskim weselu w Ewangelii św. Jana}

Termin wino (gr. oinos) w Biblii greckiej został użyty 286 razy. Święty Jan Ewangelista o napoju z owoców winorośli wspomina tylko sześć razy, zawsze w kontekście wesela w Kanie Galilejskiej ${ }^{14}$. Uroczystość zaślubin odbywa się trzeciego dnia (J 2, 1). Tak precyzyjne wskazanie ma swoje paralele starotestamentowe - również w trzecim dniu miało miejsce objawienie Boga na górze Synaj ( $\mathrm{Wj}$ 19, 11-16), połączone $\mathrm{z}$ zawarciem przymierza i nadaniem prawa; w trzecim dniu Izaak miał być ofiarowany na górze Moria $(\mathrm{Rdz} 22,4)$ i trzeciego dnia Józef wskazał swoim braciom sposób ocalenia życia ( $\operatorname{Rdz} 42,18)$. Nowotestamentowe zmartwychwstanie Jezusa, najważniejsze wydarzenie

Więcej o symbolice wina por. Słownik teologii biblijnej, red. X. Léon-Dufour, tłum. [z fr.] i oprac. K. Romaniuk, Poznań 1994, s. 1046.

14 Przemienienie wody w wino w świecie hellenistycznym kojarzyło się z szeroko rozpowszechnionym kultem Dionizosa (wino było traktowane jako krew Dionizosa). Wielu egzegetów uważa, że Jan świadomie przeciwstawia opowiadanie o cudzie Jezusa w Kanie kultowi greckiego boga. Jednak S. Mędala po przeprowadzeniu analizy diachronicznej przekonuje, że konfrontacja pomiędzy Jezusem a Dionizosem w środowisku żydowskim miała miejsce wcześniej i na poziomie tekstu Ewangelii nie odgrywała już żadnej roli. Por. Ewangelia według Świętego Jana, cz. 1, rozdz. 1-12, wstęp, tłum. z oryg., koment. S. Mędala, Częstochowa 2010, s. 349-351 (Nowy Komentarz Biblijny. Nowy Testament, t. 4, CZ. 1). 
w historii ludzkości, również ma miejsce trzeciego dnia. Można powiedzieć, że trzeci dzień określa czas wyjątkowej i szczególnej interwencji Boga w dzieje człowieka. Opisany przez Jana trzeci dzień w Kanie jest swoistym heroldem zapowiadającym Nowe Przymierze, ratujące życie, i nową ofiarę.

Na uroczystości weselne zaproszony zostaje Jezus wraz z uczniami. Ewangelista używa czasownika kaleo - wołać w stronie biernej czasu aoristum, co dosłownie tłumaczy się jako: Jezus został zawołany na wesele. Po tych wstępnych informacjach Jan od razu przechodzi do informacji o braku wina. W tekście wyraźnie zaznaczona jest różnica pomiędzy starym winem, które jest gorszej jakości i którego brakuje, a nowym, danym przez Jezusa, doskonałym i w obfitości. Ten stan braku spostrzega Matka Jezusa i informuje Syna o deficycie, jaki zaistniał. Reakcją Jezusa jest stwierdzenie, że jeszcze nie nadeszła godzina.

Teologiczne znaczenie godziny (gr. hora) w Ewangelii Jana rozpatrywane jest w trzech kategoriach: czysto chronologicznej, chrystologicznej i eschatologicznej. Znaczenie chronologiczne wskazuje na czas opowiadanego wydarzenia. Chrystologiczne zastosowanie godziny dotyczy czasu męki $(\mathrm{J} 7,30)$, również w wymiarze otoczenia chwałą $(J 17,1)$, a eschatologiczne to czas sądu $(J 5,25)^{15}$. W kontekście braku wina w Kanie godzina Jezusa jest przez Niego zapowiadana, zbawienie nie dokonało się jeszcze, ale już rozpoczął się czas bezpośrednio je poprzedzający. Kana antycypuje godzinę, a wydarzenia z godziny, które dopiero się wydarzą, z wyprzedzeniem implikują cud. W kontekście eschatologicznym przemiana wina rozpoczyna czas radości ostatecznej.

Matka Jezusa najpierw zauważa brak wina i wskazuje to Jezusowi, następnie poleca sługom ${ }^{16}$, by uczynili wszystko, o co poprosi Syn.

Por. S. Mędala, Chrystologia Ewangelii św. Jana, Kraków 2001, s. 206-207.

Ewangelista używa terminu diakonos. W języku greckim służba domowa określana jest jako dulos. Diakonos użyte przez Jana oznacza konkretną służbę Jezusowi i pomoc innym ze względu na Nauczyciela (por. ] 12, 26). 
Jezus jest uważany przez Maryję jako jedyny, który potrafi zaradzić sytuacji deficytu; z drugiej strony Matka pokazuje zebranym ludziom, że potrzebny jest wkład człowieka, zaangażowanie, podjęcie działania zgodnego z Bożą wolą. Maryja wskazuje Jezusa i prowadzi innych do swego Syna.

W pomieszczeniach, w których odbywało się wesele, znajdowało się sześć kamiennych stągwi. Liczba ta nawiązuje do sześciu dni stworzenia ( $\mathrm{Rdz} 2,2)$, człowiek miał pracować sześć dni (Wj 20,9) i ziemię należało obsiewać przez sześć lat (Wj 26, 10). To cyfra niedoskonała, poprzedzająca wyrażającą pełnię siódemkę. Biblijne sześć oznacza również moce wrogie Bogu: olbrzyma o sześciu palcach u każdej ręki i nogi (2 Sm 21, 20) czy apokaliptyczną liczbę Bestii, będącą liczbą człowieka (Ap 13, 18). Reasumując, symbolika szóstki w Biblii to przede wszystkim małość i niedoskonałość ${ }^{17}$.

George Raymond Beasley-Murray, komentujący ilość stągwi w kontekście czystości rytualnej Żydów [stągwie służyły do odzyskania czystości poprzez obmycie (rąk, naczyń), same były wykonane $\mathrm{z}$ „koszernego" budulca - kamienia], wskazuje, że ewangelista zastosował opozycję. Przeciwstawił stągwie przed cudem, które symbolizują ograniczenia Starego Przymierza, stągwiom po cudzie, oznaczającym pełnię łaski Jezusa ${ }^{18}$.

Stągwie mogły pomieścić dwie lub trzy miary. Wśród egzegetów nie ma jednoznaczności w interpretacji pojemności miary - mogła być odpowiednikiem 40 (ta wersja podawana jest częściej) lub 21 litrów ${ }^{19}$. Bez względu na tę niejednoznaczność stągwie napełniono dużą ilością wody. Ewangelista zaznacza słabość i niedoskonałość poprzez kompromitujący brak wina, wodę, która wypełnia stągwie zamiast

17 Więcej na temat symboliki liczby sześć por. Sześć, [w:] M. Lurker, Słownik obrazów isymboli biblijnych, dz. cyt., s. 234.

18 Por. G. R. Beasley-Murray, John, [w:] Word biblical commentary, Vol. 36, 2nd ed., Dallas-Texas 1999 [CD-ROM].

19 Por. Ewangelia według Świętego Jana, cz. 1, rozdz. 1-12, dz. cyt., S. 359. 
szlachetnego napoju, i użytą liczbę sześć. Wobec tej trudnej sytuacji staje Jezus, Mesjasz, który całą ułomność zmienia w doskonałość. Cud przemienienia wody w wino jest zarówno jakościowy, jak i ilościowy.

Na uroczystości weselnej pochwałę za doskonałe wino otrzymuje pan młody (gr. nymfios), który reakcją milczenia potwierdza, że to Jezus jest odpowiedzialny za podanie gościom nowego napoju. Jezus ze sceny weselnej znika w J 2, 9-10, a na Jego miejscu pojawia się nymfios - w ten sposób Jan sugeruje, że Chrystus to Pan Młody i prawdziwy Oblubieniec. Na takie znaczenie nymfios wskazuje J 3, 29, podobnie Jezusa jako Oblubieńca określają ewangelie synoptyczne (np. Mk 2, 19).

Jan konkluduje cud informacją, że „taki początek znaków uczynił Jezus" (J 2, 11a). Zaznaczając, że jest to początek, można powiedzieć, że to także archetyp znaków Mesjasza i zapowiedź tego największego ze znaków - męki i zmartwychwstania. Zarówno przy pierwszym, jak i ostatnim znaku obecna jest Matka Mesjasza.

Poprzez ten pierwszy znak Nauczyciel „objawił swoją chwałę i uwierzyli w Niego Jego uczniowie" (J 2, 11b). Przemienienie przez Jezusa wody w wino pokazuje Jego Boską chwałę i wszechmoc, które wzmacniają wiarę uczniów. Nie można powiedzieć, że cud w Kanie ją zainicjował, skoro towarzyszyli Jezusowi i od początku są nazywani uczniami.

Wszystkie użyte przez Jana czasowniki podsumowujące cud: uczynił, objawił, uwierzyli $(\mathrm{J} 2,11)$ zastosowane są w czasie aoristum, który podkreśla dokonanie w stronie czynnej. To Jezus aktywnie uczynił pierwszy znak, On objawił swoją chwałę i On spowodował, że uwierzyli uczniowie.

Cud przemienienia wody w wino opisany przez Jana nie ma swych odniesień w ewangeliach synoptycznych, dlatego na płaszczyźnie historycznej jest niesprawdzalny ${ }^{20}$. Jako gatunek literacki to opis cudu,

Przez egzegetów najczęściej przyjmowana jest hipoteza przejęcia historii cudu ze źródła znaków. Więcej na temat historyczności por. S. Mędala, Chrystologia..., dz. cyt., s. 202-203. 
który wskazuje na Jezusa i Jego Boską moc, zakłada wiarę odbiorców i do wiary prowadzi. W czwartej Ewangelii znaki uwydatniają symbolizm i to właśnie znaczenie symboliczne wydarzenia w Kanie wydaje się mieć priorytetową wartość.

Beasley-Murray pokazuje, że objawienie Bożej chwały Jezusa w cudzie wina jest realizacją zapowiedzi z J 1, 14. Słowo, które stało się ciałem i zamieszkało wśród ludzi, ukazuje swoją chwałę tym, wśród których przebywa. Chwałę, którą obdarza Jednorodzonego Ojciec $^{21}$.

Stanisław Mędala, komentując cud na weselu w Kanie, stwierdza, że ten archetypiczny znak pełni w Ewangelii Jana taką funkcję jak przemienienie Jezusa w ewangeliach synoptycznych. To antycypacja uczniów w chwale zmartwychwstałego Jezusa i równocześnie to znak programowy chrystologii Jana ${ }^{22}$.

Beasley-Murray, powołując się na J 4, 23; 5, 25, wskazuje na eschatologiczny wymiar cudu ${ }^{23}$. Po znaku w Kanie Jezus objawia swoją chwałę, ale autor zaznacza, że wierzą w Niego Jego uczniowie, ta nowa rzeczywistość jest dostępna tylko niewielkiej grupie. W kontekście eschatologicznym do udziału w chwale Boga zaproszeni są jednak wszyscy ludzie.

Jezus swoją obecnością na uroczystościach ślubno-weselnych w Kanie Galilejskiej uświęcił małżeński związek pomiędzy kobietą i mężczyzną, wskazał na sacrum, które ofiaruje małżonkom. Wprowadził nową jakość, nie tylko Nowego Przymierza, ale również tej wyjątkowej relacji międzyludzkiej.

Jezus przemienił wodę w wino, symbol radości. Stare wino, którego zabrakło, Nauczyciel z Nazaretu zastępuje nowym, wyjątkowej jakości i ilości. Pełne szczęście to radość eschatologiczna i taką właśnie symbolizuje nowe wino. Wraz ze wcieleniem Słowa, Nowym

21

22

23

Por. G. R. Beasley-Murray, John, dz. cyt.

Por. Ewangelia według Świętego Jana, cz. 1, rozdz. 1-12, dz. cyt., s. 361.

Por. G. R. Beasley-Murray, John, dz. cyt. 
Przymierzem i nową jakością życia rozpoczął się czas tej nowej, wyjątkowej radości.

\section{Zakończenie}

Opisane przez św. Jana przemienienie wody w wino, którego dokonał Jezus na weselu w Kanie Galilejskiej, jest pierwszym znakiem w czwartej Ewangelii, archetypem znaków.

Miłość małżeńska od najdawniejszych czasów była czymś ważnym i wyjątkowym. Autorzy biblijni, przedstawiając więź małżeńską, próbowali zobrazować miłość Boga do człowieka. W kulturze i mentalności ludzkiej moment zawierania małżeństwa był wyjątkowy. Starannie się do niego przygotowywano i uroczyście celebrowano. Jezus, goszcząc na zaślubinach, uświęcił związek pomiędzy kobietą i mężczyzną, wprowadził nową jakość w tej relacji.

Obrzędom weselnym towarzyszyło wino, popularny napój w starożytnym Izraelu. Często wspominany w Piśmie Świętym, był uznawany za symbol radości i szczęścia, jeżeli tylko go nie nadużywano. Biblia stanowczo piętnuje pijaństwo, uważając je za głupotę, a ceni umiar.

Czasy smutku, grzechu i karania niewierności cechuje brak wina, a radości, szczęścia, spełnienia i wierności - jego obfitość. Wino z Kany Galilejskiej, którego zabrakło, symbolizuje epokę przed Chrystusem, stare czasy, Stare Przymierze i stare, niedoskonałe prawo. Nowe wino, które daje Jezus, to nowa jakość życia, nowe czasy i Nowe Przymierze. To nowa radość eschatologicznego uwielbienia i chwały.

Jezus cudu w Kanie dokonuje w trzecim dniu, czyli w czasie wyjątkowej interwencji Boga w dzieje ludzkości. Przemienienie wody w wino zapowiada godzinę Jezusa, a więc czas męki i zmartwychwstania, oraz rozpoczyna godzinę eschatologiczną.

W centrum wydarzeń w Kanie ewangelista umieścił Jezusa. Na Niego wskazuje wierząca w Syna Matka, wierzą w Niego również uczniowie. Jezus, przemieniając wodę $\mathrm{w}$ wino, pokazuje swoją wszechmoc, zamieniając to, co ułomne, $\mathrm{w}$ to, co doskonałe, stare w nowe. 
Jezus, Pan Młody i prawdziwy Oblubieniec, ukazany przez św. Jana na weselu w Kanie objawia swoją chwałę i wprowadza czas prawdziwej radości. Dar wina, ofiarowany gościom weselnym, nic nie kosztuje, tak jak miłość, którą Bóg ofiaruje człowiekowi. I to właśnie miłość bezinteresowna i ofiarna jest uczuciem, które powinno łączyć małżonków. Miłość, która, jak twierdzi Silvano Fausti, łączy Stare Przymierze z Nowym ${ }^{24}$, i miłość wraz z radością symbolizowaną przez wino naznacza czas eschatologicznego dokonania, kiedy to ludzie

nie zaznają głodu ani pragnienia, już nie porazi ich słońce ani żaden upał, bo będzie ich pasł Baranek stojący na środku tronu. On poprowadzi ich do źródła wody życia, a Bóg otrze z ich oczu każdą łzę. (Ap 7, 16-17)

24 Por. S. Fausti, Rozważaj igłoś Ewangelię. Wspólnota czyta Ewangelię według św. Jana, tłum. B. A. Gancarz, Kraków 2005, s. 52. 